一技術報告一

Bacillus cereus の VNTR 型解析による法科学的土壌資料の異同識別

\author{
吉川ひとみ*1，藤浪良仁*1，横山栄二*2，杉田律子*1，安田二朗*1，鈴木真一*1 \\ 科学警察研究所*1, 千葉県衛生研究所*2 \\ 厂277-0882 千葉県柏市柏の葉 6-3-1*1 \\ 厂260-8715 千葉市中央区仁戸名町 $666-2 * 2$
}

\title{
Discrimination of Forensic Soil Samples Using Variable-Number Tandem Repeat Typing of Bacillus cereus
}

\author{
Hitomi S. Kikkawa*1, Yoshihito Fujinami*1, Eiji Yokoyama*2, Ritsuko Sugita*1, \\ Jiro Yasuda*1 and Shinichi Suzuki*1 \\ National Reseach Institute of Police Science*1 \\ 6-3-1 Kashiwanoha, Kashiwa, Chiba 277-0882, Japan \\ Chiba Prefectural Institute of Public Health*2 \\ 666-2, Chuo, Chiba, Chiba 260-8715, Japan
}

(Received 28 May 2008; accepted 4 July 2008)

Soil is one of the most important physical evidence in criminal investigations, which provides useful information regarding with the relations between suspects, victims and crime scenes. Forensic soil samples are conventionally discriminated based on physical properties, such as color and mineral examinations. It is considered that molecular analysis of DNA of soil bacteria can contribute to the criminal investigation substantially, because improvement of discrimination ability of soil will be achieved by addition of biological analysis. This report describes the application of molecular analysis, which is used for discrimination of pathogens in epidemiological investigations, to forensic soil samples. Samples were taken from three sites (A, B and C), and sites B and C, which were $300 \mathrm{~m}$ apart, were located about $42 \mathrm{~km}$ from site A. Discrimination of soil samples by color and X-ray diffraction analyses were difficult. Then, Bacillus cereus was isolated from the small amount of soil samples which were as little as the lowest quantity required by the conventional method, and discriminated by variable-number tandem repeat (VNTR). The result showed that two VNTR types isolated from A were not included among isolates from $\mathrm{B}$ and $\mathrm{C}$ even 2 years later. These results suggested that the VNTR analysis using Bacillus cereus might be useful for the discrimination of forensic soil sample analysis. However, Bacillus cereus isolate shows a diversity even isolated from the same soil, therefore further data collection is required to evaluate this method for forensic soil identification. 


\section{Key words: Forensic soil analysis, Microbial analysis, Molecular analysis, Bacil- lus cereus, Variable-number tandem repeat (VNTR)}

\section{緒 言}

土壤は様々な犯罪現場において証拠資料として, 被疑者と犯罪現場の結びつきを証明する重要な手が かりとなりうる11．現在，土㙥の鑑定は主として色 調や鉱物組成など土壤学的あるいは鉱物学的な検査 によって行われている2-6).これらの手法は有用で あるが，検査に比較的多くの分析試料を必要とする ことから微量な証拠物件では適用が難しい場合もあ り，また，数 $\mathrm{km}$ 以上離れた地点から採取した土壤 であっても類似した鉱物組成を示し，識別困難であ ることもある。土㙋試料の鑑定検査において，土㙥 学的あるいは鉱物学的な検査に加え, これまで用い られてきたものとは異なる生物学的な指標を利用す ることにより識別能力の向上を図ることができれ ば，犯罪捜査に多大な貢献が期待できる.

微生物を利用した土䁃資料の異同識別は, 酵素活 性の差異を利用した方法などにより以前から試みら れてきた7)。近年では, terminal restriction fragment length polymorphism (T-RFLP) 法や16S rRNA 遺伝子の amplicon length heterogeneity-polymerase chain reaction (ALH-PCR) 法による土壌試 料中の細菌種の相違を資料の判別に用いた研究が活 発に行われており，鑑定資料の異同識別8 や地域推 定に有効と考えられる情報を把握できるという報告 がある8-10). しかしながら，これら網羅的解析手法 は環境の変化に極めて影響を受けやすく $11-14) ， \mathrm{~T}-$ RFLP 法を法科学的資料に応用した場合には 8 ヶ月 後に解析すると由来が同じ土䁃であっても異なるパ ターンを示すことも報告されている ${ }^{8)}$. そこで, 法 科学的にはより変化が遅く長期的に安定な指標を選 択する必要があった。近年，食中毒や院内感染事案 に拈いて病原菌の近縁関係による感染経路の特定 や, 関連菌株か否かを判別するために variable number tandem repeats（VNTR）の分析による多型 解析, パルスフィールドゲル電気泳動 (PFGE) 法 による解析，あるいは amplified fragment length polymorphism (AFLP) 法による解析が行われてい
る15-17)。 ある細菌種から検出される DNA 型は同一 事案由来の菌株を解析した場合には非常に類似した パターンを示すため，同種の細菌の近縁関係を解析 するための方法として用いられており, 疫学調査に 信頼できる值を与えるとされている15,16)．これら型 判定の手法のうち, VNTR の解析は手技が簡便で かつ結果を得るまでに要する時間が少ないという利 点があり，実際の鑑定へ適応するにはより適してい る手法であると推測される.

本研究では, 分子疫学的な細菌株解析手法を土壌 資料の異同識別に応用する目的で単離土䁃細菌の VNTR 型判定を行った。解析の対象の細菌種は, 土壤に広く分布し，さらに芽胞を形成することなど により環境変化に強いものが望ましいと考えられ る. 土壤中に生息する芽胞形成菌のうち Clostridium tetani, Clostridium botulinum, そして Bacillus anthracisなどの病原性が高いものは扱いが難し く, 実用性を考慮した場合, 病原性が低い Bacillus cereus $^{18)}$ が最も適していると考えられる。そこで Bacillus cereus の VNTR 型判定による解析法が土 壤識別に有用となる可能性があるか否かを検討し た.

\section{1. 試料}

\section{材料および方法}

土壤試料は東京都内の $\mathrm{A}$ 地点から 2 ヶ所 ( $\mathrm{A} 1$, $\mathrm{A} 2)$, 千葉県内の B 地点から 4 ヶ所（B1-B4）打よ び千葉県内の $\mathrm{C}$ 地点から 6 ヶ所 $(\mathrm{C} 1-\mathrm{C} 6)$ の合計 12 ヶ所から採取した。試料採取地点はいずれも関東 ローム層の分布地域であり，従来の方法では異同識 別が難しいと予想される． B 地点と C 地点は約 300 $\mathrm{m}$ 離れて抢り（近距離比較のため), これらは更に $\mathrm{A}$ 地点から約 $42 \mathrm{~km}$ 離れている（遠距離比較のた め). 各地点では直線状に約 0.5-1 m 間隔で約 5-10 $\mathrm{cm}$ の深さから試料の採取を行った。 2005 年 5 月 6 日には 3 地点 12 ヶ所全てから，2007年には B, C 両 地点の採取場所の打打むね中央に位置している C3 
地点（5月 7 日）, $\mathrm{B} 3$ および $\mathrm{C} 4$ 地点（7月 3 日） から土壌試料を採取した。

\section{2. 色調および $\mathbf{X}$ 線回折による鉱物成分の検査}

色調検查抢よびX 線回折は Marumo et al. ${ }^{2,3)}$ お よびSugita and Marumo4) に従い行った。すなわ ち, 試料のうち $2 \mathrm{~mm}$ 以下の粒子を過酸化水素水を 加えて有機物分解を行った後, 粒径 $0.05 \mathrm{~mm}$ 以上 (砂画分）はアジレラージャクソン法19)で，粒径0.05 $\mathrm{mm}$ 以下（粘土画分）はメーラージャクソン法 ${ }^{20)} に$ より脱鉄処理を行った。砂画分については, ブロモ ホルム（比重2.9）を用いて重鉱物画分と軽鉱物画 分に分離した．色調検査は風乾試料，有機物分解後 の粘土画分および脱鉄後の粘土画分について Sugita and $\mathrm{Marumo}^{4)}$ に従い標準土色帖21) 用いて行っ た. X 線回折は縦型ゴニオメータ付 RINT2500型 X 線回折装置（リガク社製）を用いて，砂画分の軽鉱 物と粘土画分について測定を行った．砂画分につい ては，粉砕した試料約 $2.0 \mathrm{mg}$ をコロジオンを用い て無反射板に塗り広げて不定方位標本を作製し，測 定に用いた．粘土画分についてはカリウムまたはマ グネシウム飽和の定方位標本を作製し，カリウム飽 和標本は風乾， $300^{\circ} \mathrm{C} て ゙ 1$ 時間加熱したもの抢よび $600^{\circ} \mathrm{C}$ で 1 時間加熱したもの，また，粘土画分のマ グネシウム標本は風乾したものとグリセロール処理 したものを測定した. 測定条件を Table 1 に示す.

\section{Bacillus cereus の分離および同定}

(1) Bacillus cereus 様細菌の分離

芽胞非形成菌を死滅させる目的で，200 $\mu \mathrm{g}$ の土 壤試料を $70 \%$ エタノールに懸濁して室温で 1 分間放 置したのち遠心操作 $\left(100 \times \mathrm{g}, 5 \mathrm{~min}, 4^{\circ} \mathrm{C}\right)$ を行い, 上清を取り除いた。エタノール処理後の沈殿を滅菌

Table 1 Experimental conditions for X-ray diffraction (XRD).

\begin{tabular}{lcc}
\hline \multicolumn{1}{c}{ XRD conditions } & Sand fraction & Clay fraction \\
\hline Target & $\mathrm{Cu}$ & $\mathrm{Cu}$ \\
X-ray tube voltage & $40 \mathrm{kV}$ & $40 \mathrm{kV}$ \\
X-ray tube current & $40 \mathrm{~mA}$ & $100 \mathrm{~mA}$ \\
Monochromator & Graphite & Graphite \\
Measurement range & $3 \sim 70^{\circ}(2 \theta)$ & $3 \sim 20^{\circ}(2 \theta)$ \\
Scan speed & $4^{\circ} / \mathrm{min}$ & $1^{\circ} / \mathrm{min}$ \\
\hline
\end{tabular}

精製水 $1 \mathrm{ml}$ に懸濁した後, $4^{\circ} \mathrm{C} て ゙ 400 \times \mathrm{g}, 5$ 分間遠 心操作を行い, 得られた上清の $50 \mu \mathrm{l}$ を Bacillus cereus group の選択培地である NGKG 培地（日水 製薬株式会社製）に塗沫して，好気性条件下に抢い て $32^{\circ} \mathrm{C} て ゙ 一$ 晚培養した. Bacillus cereus group の特 徵であるレシチナーゼ活性を有するコロニーを再び 10\%にヒツジ血液を加した普通寒天培地（日水製薬 株式会社）に塗沫し，溶血活性を持つコロニーを再 度普通寒天培地を用いて純化し分離菌とした。分離 は2005年 5 月，2007年 5 月， 7 月に行った。 2005年 5 月に分離を行った際には, 実際の鑑定では試料の 状態によってはコロニーが少数しか得られない可能 性があることから，1 ケ所につき 1 つのコロニーを 無作為に抽出して分析を行った. 2007年の 5 月には $\mathrm{C} 3$ 地点から，7 月には B3 抢よび C4 地点から分離 操作を行い, Bacillus cereus 様コロニーを全て分離 した。

(2) Bacillus cereus $の$ 種名同定

分離株のコロニーを $20 \mu \mathrm{l}$ の $0.25 \%$ ドデシル硫酸 ナトリウム含有 $50 \mathrm{mM}$ 水酸化ナトリウム溶液に懸 濁し, $95^{\circ} \mathrm{C} て ゙ 15$ 分間加熱した. その後遠心操作 $\left(16,000 \times \mathrm{g}, 5 \mathrm{~min}, 4^{\circ} \mathrm{C}\right)$ を行い, 上清をポリメラー ゼ連鎖反応 (PCR) の鋳型として, i-Cycler（Bio$\operatorname{Rad}$ 社製）を用いて以下のようにBacillus 属特異的 領域抢よび Basillus cereus group 特異的な領域であ るホスホリパーゼ C (cerA) 領域を標的とした PCR 増幅を行った 22,23). PCR 反応液は, KOD dash reaction buffer, $200 \mu \mathrm{M}$ の 4 種 $\mathrm{dNTP}, 0.65 \mathrm{U}$ KOD dash DNA ポリメラーゼ（東洋紡績株式会社 製)， $1 \mu \mathrm{M}$ プライマーを含み，全量を $20 \mu \mathrm{l}$ とし た。なお，Bacillus 属特異的領域の増幅は $\mathrm{BacF}$ (30)-BacR プライマー22)を用いて, $94^{\circ} \mathrm{C} 60$ 秒， 57 ${ }^{\circ} \mathrm{C} 60$ 秒， $72^{\circ} \mathrm{C} 60$ 秒の温度条件を 30 サイクル，更に $72^{\circ} \mathrm{C} 3$ 分間の伸長反応を行った (Table 2). cer $A$ 領域は Schraft and Griffiths の方法に従い23), Table 2 に示すプライマーを用いて増幅を行った. 増幅後 の反応液は $1.2 \%$ アガロースゲル電気泳動を行った 後, エチジウムブロマイドで染色し, Bacillus 属特 異的領域については約 $600 \mathrm{bp}, \operatorname{cer} A$ 領域では約 400 bpの増幅バンドの有無を確認した.

Bacillus cereus と Bacillus thuringiensis の識別に 


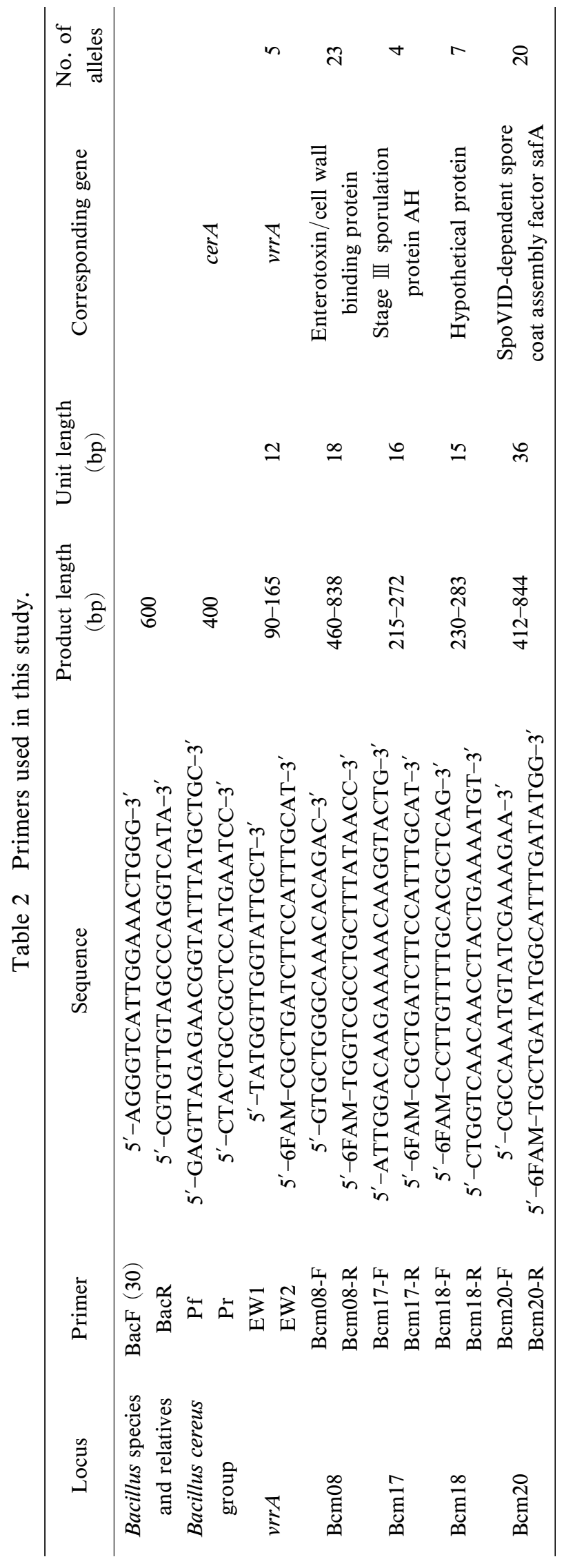

ついては, Ohba et al. の方法 ${ }^{24,25)}$ に準じ位相差顕 微鏡を用いて観察を行い, 結晶蛋白質の有無により 種名判定を行った.

（3）VNTR 領域の PCR 増幅および型判定

蛋白質および細胞由来の夾雑物を取り除く目的 で，3.(2)でPCR 反応に用いた菌体抽出液をフェ ノールークロロホルムーイソアミルアルコール処理を 行った後エタノール沈殿を行い, VNTR 解析の鋳 型とした。多数のBacillus cereus 株を用いた報告が あり識別力が確認されているVNTR 5 領域の解析 を行った26-28). 検討に用いた VNTR 領域の増幅に 用いたプライマーは Table 2 に示すとおりであり， i-Cyclerを用いて既報に従い増幅を行った ${ }^{26-28)}$. PCR は, KOD dash reaction buffer, $5 \mathrm{ng}$ の鋳型 DNA, 0.65 U KOD dash DNA polymerase, $200 \mu \mathrm{M}$ の 4 種 $\mathrm{dNTP}, 0.5 \mu \mathrm{M}$ のプライマーを含んだものを 超純水にて全量を $20 \mu \mathrm{l}$ にした。 $\mathrm{Bcm} 08, \mathrm{Bcm} 17$, $\mathrm{Bcm} 18$ ，および $\mathrm{Bcm} 20$ の PCR 増幅は， $96^{\circ} \mathrm{C} 5$ 分の 熱変性後, $96^{\circ} \mathrm{C} 30$ 秒, $56^{\circ} \mathrm{C} 60$ 秒, $70^{\circ} \mathrm{C} 60$ 秒のサイ クルを30回繰り返し, $70^{\circ} \mathrm{C}$ で 5 分伸長反応すること により行った。 $v r r A$ 部位は, $94^{\circ} \mathrm{C} 60$ 秒の熱变性 後, $94^{\circ} \mathrm{C} 60$ 秒, $55^{\circ} \mathrm{C} 60$ 秒, $72^{\circ} \mathrm{C} 60$ 秒のサイクルを 30 回繰り返し, $72^{\circ} \mathrm{C}$ で 10 分伸長反応を行い増幅し た。

PCR 産物の検出は, 泳動ポリマーとして POP-7 (Applied Biosystems 社製) を使用し，ABI 3130 Avant Genetic Analyzer (Applied Biosystems 社製) を用いて行った。 $1 \mu \mathrm{l}$ の希釈 PCR 産物を $1 \mu \mathrm{l}$ の GeneScan 1200 LIZ サイズスタンダードマーカー (Applied Biosystems 社製) とともに20 $\mu \mathrm{l} の \mathrm{Hi}-\mathrm{Di}$ Formamide (Applied Biosystems 社製) に加え, 95 ${ }^{\circ} \mathrm{C} て ゙ 5$ 分間の加熱变性を行い検出用試料とした.

\section{結果および考察}

\section{1.色調および $\mathbf{X}$ 線回折による検査結果}

本研究の試料が鉱物学的な特徵により識別可能で あるか検查する目的で，現在，土㙥資料の異同識別 法として日本で用いられている色調検査およびX 線回折による鉱物成分の検査を行った．色調検査の 結果, 試料間の色調の差異は標準土色帖 ${ }^{21)}$ の隣接す る2枚のカラーチップの範囲内であった（Table 
3). 隣接する 2 枚のカラーチップの色調を示す土壌 試料は識別困難とされており4), 色調検査では試料 の識別は困難であることが明らかとなった。 また， $\mathrm{X}$ 線回折による検査を行ったところ ${ }^{2,3)}$ ，軽鉱物画 分および粘土画分共に含有する鉱物の組み合わせは 類似していた (Table 4). よって, 本研究で用いた 試料は色調検査のみならず，X線回折による識別 も難しいことが判明した。

\section{2. 細菌の分離および特定}

本研究で用いたすべての土壌試料から，レシチ ナーゼ活性および溶血活性を有する Bacillus cereus 様コロニーを得ることができた．分離した菌株から DNAの抽出を行い, Bacillus 属の細菌を特異的に 増幅する $\operatorname{BacF}(30)$ - BacR プライマー22)を用いた PCR 増幅を行った結果，2005年に得られた C4 地 点の株および2007年 7 月に得られた B3 地点の 2 株 以外は全ての分離株で約600 bp のサイズの増幅バ ンドが認められた。2005年に分離した株の PCR 増 幅結果をFig. 1Aに示す。をた，Bacillus cereus groupのみ増幅する cer $A$ を標的とした Pf-Prプラ イマー23)を用いて増幅を行った結果，2005年，2007 年全ての分離菌で約 $400 \mathrm{bp}$ のサイ゙のバンドを確 認した。 Fig. 1Bに2005年分離株のPCR 増幅結果 を示す。これらの結果により，分離した細菌は Bacillus cereus group であると考えられた.Bacillus cereus group 特異的 PCR で増幅されるにもかかわ らず，Bacillus 属特異的 PCR での増幅がみられな かった分離株が 3 株あったが，これはプライマーの 領域に変異が入っているなどの原因が考えられた.

Bacillus cereus group は Bacillus cereus とそのき わめて近縁の 3 種の細菌で構成されるグループであ り，溶血活性を有する Bacillus cereus および Bacillus thuringiensis とこの活性を持たないBacillus mycoides と Bacillus anthracis から成っている. 分 離株はすべて溶血活性を持つことから, Bacillus cereus group のなかの Bacillus cereus または Bacillus thuringiensisであると考えられた。 そこで, 全 ての分離株を位相差顕微鏡下で観察したところ,

Table 3 Results of color examination of soil samples.

\begin{tabular}{|c|c|c|c|c|c|c|}
\hline Sample treatment & A1 & $\mathrm{A} 2$ & B1 & B2 & B3 & B4 \\
\hline Air-drying & $10 \mathrm{YR} 4 / 3$ & $10 \mathrm{YR} 4 / 3$ & $10 \mathrm{YR} 4 / 3$ & $10 \mathrm{YR} 4 / 3$ & $10 \mathrm{YR} 3 / 4$ & $10 Y R 3 / 3$ \\
\hline Decomposition of organic matter & 10YR6/4 & 10YR6/4 & $10 \mathrm{YR} 7 / 4$ & 10YR6/4 & $10 Y R 5 / 4$ & $10 Y R 5 / 4$ \\
\hline Removal of iron & 10YR6/4 & 10YR6/3 & 10YR6/4 & 10YR6/4 & $10 \mathrm{YR} 5 / 3$ & 10YR6/3 \\
\hline Sample treatment & $\mathrm{C} 1$ & $\mathrm{C} 2$ & $\mathrm{C} 3$ & $\mathrm{C} 4$ & $\mathrm{C} 5$ & C6 \\
\hline Air-drying & $10 \mathrm{YR} 4 / 2$ & $10 \mathrm{YR} 4 / 2$ & $10 \mathrm{YR} 4 / 3$ & $10 Y R 4 / 3$ & $10 \mathrm{YR} 4 / 3$ & $10 \mathrm{YR} 3 / 3$ \\
\hline Decomposition of organic matter & 10YR6/4 & 10YR6/6 & 10YR6/4 & 10YR6/5 & $10 \mathrm{YR} 7 / 4$ & $10 \mathrm{YR} 6 / 4$ \\
\hline Removal of iron & $10 Y R 6 / 4$ & 10YR6/4 & $10 Y R 6 / 4$ & $10 Y R 6 / 4$ & 10YR6/4 & $10 Y R 6 / 3$ \\
\hline
\end{tabular}

Table 4 Mineralogical compositions of soil samples by $\mathrm{XRD}^{\mathrm{a})}$.

\begin{tabular}{|c|c|c|c|c|c|c|c|c|c|c|c|c|c|}
\hline Fraction & Mineral names & $\mathrm{A} 1$ & $\mathrm{~A} 2$ & B1 & $\mathrm{B} 2$ & B3 & B4 & $\mathrm{C} 1$ & $\mathrm{C} 2$ & $\mathrm{C} 3$ & $\mathrm{C} 4$ & $\mathrm{C} 5$ & $\mathrm{C} 6$ \\
\hline \multirow{4}{*}{$\begin{array}{l}\text { Light minerals } \\
\text { fraction }\end{array}$} & Quartz & + & + & + & \pm & \pm & \pm & + & \pm & + & \pm & + & \pm \\
\hline & Cristobalite & - & - & - & - & - & - & \pm & \pm & - & + & - & - \\
\hline & Plagioclases & \pm & \pm & + & + & + & + & + & + & \pm & + & \pm & + \\
\hline & Amphibole & - & - & \pm & - & - & - & - & - & - & - & - & - \\
\hline \multirow{4}{*}{ Clay fraction } & Chlorite & $H$ & $H$ & + & + & + & + & + & + & + & + & + & + \\
\hline & Mica & $H$ & $H$ & + & + & \pm & - & H & + & + & + & \pm & - \\
\hline & Kaolin Minerals & $H$ & H & + & + & + & + & H & + & + & + & + & + \\
\hline & Hydroxide Minerals & \pm & \pm & H & H & H & + & + & \pm & H & + & H & + \\
\hline
\end{tabular}

a) Abundance: + abundant, + medium, \pm little, - none 
A

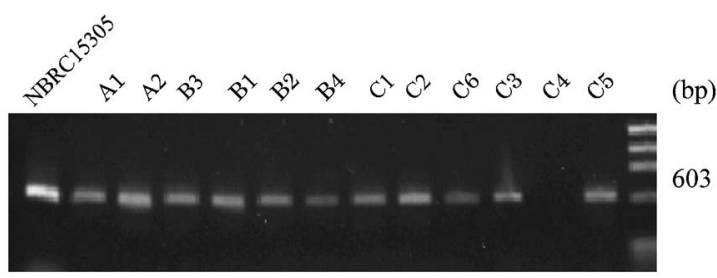

B

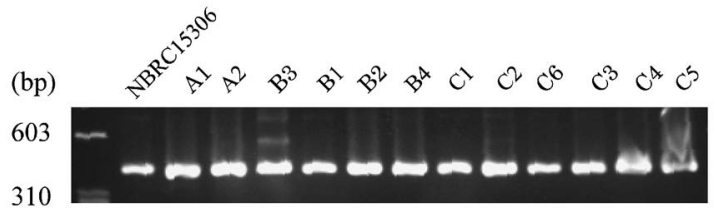

Fig. 1 Identification of isolated bacteria species. Gel electrophoresis of PCR products amplified with primers BacF (30)-BacR (A) and $\mathrm{Pf}-\mathrm{Pr}$ (B). Twelve Bacillus cereus isolates (A1 2005, A2 2005, B1 2005, B2 2005, B3 2005, B4 2005, C1 2005, C2 2005, C3 2005, C4 2005, C5 2005, C6 2005) are included.

Bacillus thuringiensis に特徵的な結晶性蛋白質を持 つものは見られなかったことから，分離株はBacillus cereus であると確認された（Fig. 2). 本実験で は色調検査およびX 線回折による検査での検査可 能な最下限量の土壌試料を実験に供したが複数の Bacillus cereus 分離株を得ることが可能であり, 現 行法より少量の試料で土壤由来細菌が解析可能であ ることが示唆された．化学的な処理により土壌中の 微生物が死滅してしまう可能性があるため, 微生物 解析用試料は鑑定検查の初期段階で分取し, 従来法 の検査試料とは別に扱うべきであると考えられた。

\section{VNTRによる細菌株の DNA 型分析}

本研究では, 多数の Bacillus cereus 株を用いた報 告があり識別力が確認されている5つのVNTR 領 域を用いて解析を行った。分離株の解析結果を Table 5 に示す. 1 ヶ所につき 1 つのコロニーを分 離した2005年の株の解析結果では, A 地点由来株 の VNTR 型は B, C 地点由来株のいずれとも異なっ て扔り, 特に vrrA 領域と Bcm17領域では $\mathrm{B}, \mathrm{C}$ 地 点由来株と一致しているものはみられなかった。こ の結果は， $\mathrm{A}$ 地点が $\mathrm{B}$ 抢よび $\mathrm{C}$ 地点から $42 \mathrm{~km}$ と 比較的遠距離であったことと関連している可能性が 推測される. 一方, $\mathrm{B}$ 地点扔よび $\mathrm{C}$ 地点から得ら れた株にはVNTR 型が類似したものも見られ, 特

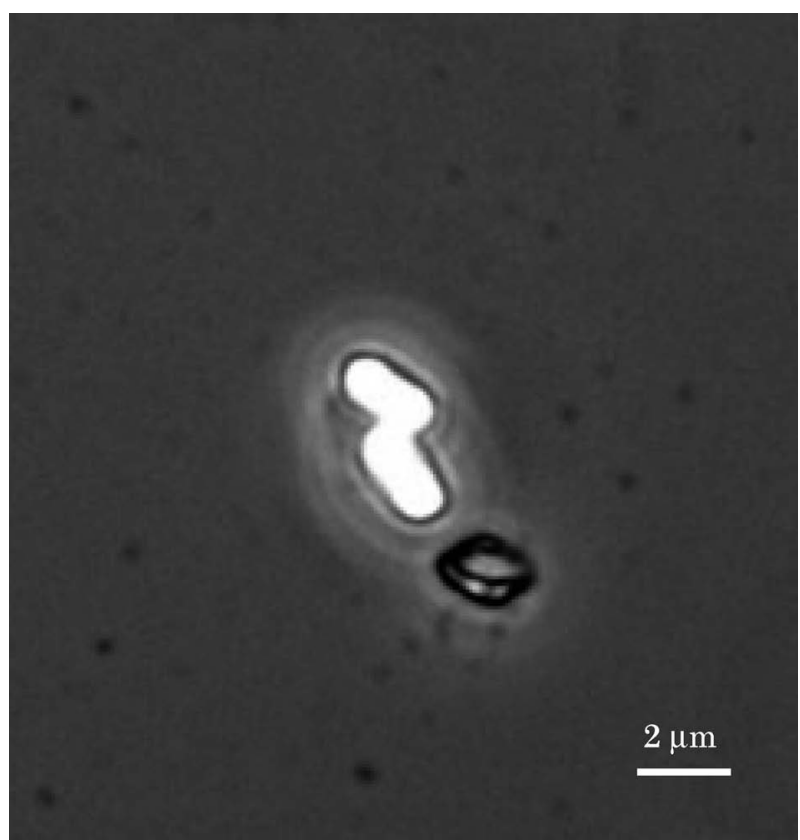

Fig. 2 Phase-contrast photograph of isolated Bacillus cereus (B4 2005). Crystal toxin is not observed.

にB1 2005 とC4 2005，B3 2005とC2 2005は完全に 一致し,さらにこれらの株間の違いは $\mathrm{Bcm} 20$ の繰 り返し数が一つ変化しているのみであった。これは $\mathrm{B}, \mathrm{C}$ 地点が約 $300 \mathrm{~m}$ と近接した地点であることが 関与している可能性が推測される。 そこで, 我々は 約 2 年後の $\mathrm{C} 3$ 地点 (2007年 5 月), B3 および C4 地点（2007年 7 月）から資料を採取し，すべてのコ ロニーを分離して解析を試みた。その結果，C4 39 に見られるように, 同一地点由来株のVNTR 型 は類似している傾向が見られたものの，C3 あるい はB3 では様々なVNTR 型が見られ，コロニー間 あるいは経時的にも多様性があることが確認され た。しかしながら，このなかに A 地点からの型に 一致するものは見られなかった。

一つの試料から複数のVNTR 型が認められた が，その理由として土壌中に元来，多様な VNTR 型のBacillus cereus が存在している可能性がある.

微量な土䁃資料中の Bacillus cereus は湿度の低下に より芽胞を形成するが，分離されるのは元の土壌中 で最も優勢な, すなわち数の多い遺伝子型の Bacillus cereus であると予想される. よって, 土䁃資料 
Table 5 VNTR types of 44 Bacillus cereus isolates from soil.

\begin{tabular}{|c|c|c|c|c|c|c|c|}
\hline \multirow{2}{*}{ Sample } & \multirow{2}{*}{$\begin{array}{l}\text { Sampling } \\
\text { site }\end{array}$} & \multirow{2}{*}{$\begin{array}{c}\text { Date of } \\
\text { sampling }\end{array}$} & \multicolumn{5}{|c|}{ Number of repeat in each VNTR locus } \\
\hline & & & vrrA & Bcm08 & $\mathrm{Bcm} 17$ & $\mathrm{Bcm} 18$ & $\mathrm{Bcm} 20$ \\
\hline A1 2005 & A1 & \multirow{12}{*}{ 6-May-05 } & 8 & 27 & 9 & 10 & 9 \\
\hline A2 2005 & $\mathrm{~A} 2$ & & 10 & 27 & 9 & 10 & 13 \\
\hline B1 2005 & B1 & & 5 & 27 & 8 & 10 & 12 \\
\hline B2 2005 & $\mathrm{~B} 2$ & & 9 & 27 & 8 & 10 & 8 \\
\hline B3 2005 & B3 & & 5 & 27 & 8 & 10 & 13 \\
\hline B4 2005 & B4 & & 9 & 27 & 8 & 11 & 8 \\
\hline C1 2005 & $\mathrm{C} 1$ & & 5 & 26 & 8 & 10 & 12 \\
\hline C2 2005 & $\mathrm{C} 2$ & & 5 & 27 & 8 & 10 & 13 \\
\hline C3 2005 & $\mathrm{C} 3$ & & 9 & 26 & 8 & 10 & 13 \\
\hline C4 2005 & $\mathrm{C} 4$ & & 5 & 27 & 8 & 10 & 12 \\
\hline C5 2005 & $\mathrm{C} 5$ & & 5 & 27 & 8 & 8 & 11 \\
\hline C6 2005 & C6 & & 6 & 27 & 8 & 10 & 8 \\
\hline C3 1 & \multirow{14}{*}{$\mathrm{C} 3$} & \multirow{14}{*}{ 7-May-07 } & 5 & 27 & 8 & 10 & 12 \\
\hline C3 2 & & & 5 & 27 & 8 & 10 & 12 \\
\hline C3 3 & & & 5 & 27 & 8 & 10 & 12 \\
\hline C3 4 & & & 6 & 27 & 8 & 10 & 13 \\
\hline C3 5 & & & 8 & 28 & 9 & 10 & 15 \\
\hline C3 6 & & & 8 & 28 & 9 & 10 & 15 \\
\hline C3 7 & & & 5 & 27 & 8 & 10 & 13 \\
\hline C3 8 & & & 5 & 27 & 8 & 7 & 7 \\
\hline C3 9 & & & 5 & 26 & 9 & 9 & 7 \\
\hline C3 10 & & & 5 & 26 & 8 & 10 & 13 \\
\hline C3 11 & & & 6 & 26 & 8 & 10 & 13 \\
\hline C3 12 & & & 6 & 27 & 8 & 10 & 12 \\
\hline C3 13 & & & 6 & 28 & 9 & 9 & 13 \\
\hline C3 14 & & & 9 & 27 & 8 & 10 & 13 \\
\hline B3 1 & \multirow{8}{*}{ B3 } & \multirow{18}{*}{ 3-Jul-07 } & 5 & 24 & 8 & 10 & 12 \\
\hline B3 2 & & & 5 & 27 & 8 & 10 & 11 \\
\hline B3 3 & & & 5 & 26 & 8 & 10 & 12 \\
\hline B3 4 & & & 9 & 28 & 8 & 10 & 13 \\
\hline B3 5 & & & 9 & 28 & 8 & 10 & 13 \\
\hline B3 6 & & & 5 & 28 & 8 & 10 & 14 \\
\hline B3 7 & & & 5 & 28 & 8 & 10 & 14 \\
\hline B3 8 & & & 8 & 28 & 8 & 10 & 13 \\
\hline C4 1 & \multirow{10}{*}{$\mathrm{C} 4$} & & 5 & 26 & 9 & 10 & 14 \\
\hline C4 2 & & & 5 & 27 & 9 & 9 & 9 \\
\hline C4 3 & & & 5 & 27 & 9 & 9 & 13 \\
\hline C4 4 & & & 5 & 27 & 9 & 9 & 13 \\
\hline C4 5 & & & 5 & 27 & 9 & 9 & 13 \\
\hline C4 6 & & & 5 & 27 & 9 & 9 & 13 \\
\hline C4 7 & & & 5 & 27 & 9 & 9 & 13 \\
\hline C4 8 & & & 5 & 27 & 9 & 9 & 13 \\
\hline C4 9 & & & 5 & 27 & 9 & 9 & 13 \\
\hline C4 10 & & & 5 & 28 & 9 & 9 & 14 \\
\hline
\end{tabular}

a) Not detected 
からは出来るだけ多くの Bacillus cereus を分離して 優勢な遺伝子型が何であるのかを調べる必要がある かもしれない。本実験では, 当初 $\mathrm{A}$ 地点からの採 取箇所を 2 ヶ所に，また 1 地点 1 株と設定したこと から，A 地点でのコロニー間の多様性を明らかに することができなかった．2007年資料からの結果か ら推測すると, A 地点でも多様な型が存在する可 能性がある.しかしながら, B, C 地点では 2 年経 過してもA 地点で見られる型は認められなかった ことから, ある程度以上距離が離れている場合には さらに多くのデータを積み重ねることにより，本法 は新たな土壌試験法として有効となるかもしれない と考えられる.

本研究では, 分子疫学的細菌株解析手法を法科学 的土壌資料の解析に適応した.その結果, 1 地点 1 株の解析であっても，また時間を経て採取された資 料を用いた場合でも, 比較的距離がある地域から採 取した株には差異が認められる可能性が推測され た。これまでに土壤由来細菌の VNTR 型解析によ る異同識別を試みた例はなく, 本法は法科学的な環 境由来証拠物件の検査の新たな可能性を示すもので あると考えられる。

\section{謝 辞}

本研究を行うにあたり, 九州大学の大庭道夫教授 には Bacillus thuringiensis の識別について丁寧なご 指導とご助言を頂きました．この場を借りて謝意を 表させていただきます。

\section{文 献}

1) Murray, R. C.: Evidence from the Earth. pp. 52 -53, Moutain Press Publishing Company, Montana (2004).

2) Marumo, Y. Nagatsuka, S. and Oba, Y.: Clay mineralogical analysis using the $<0.05-\mathrm{mm}$ fraction for forensic science investigation-its applicaion to volcanic ash soils and yellow-brown forest soils. J. Forensic Sci., 31, 92-105 (1986).

3) Marumo, Y. Nagatsuka, S. and Oba, Y.: Rapid clay mineralogical analysis for forensic science investigation-clay mineralogy over the short dis- tance. J. Forensic Sci., 33, 1360-1368 (1988).

4) Sugita, R. and Marumo, Y.: Validity of color examination for forensic soil identification. Forensic Sci. Int., 83, 201-210 (1996).

5) Sugita, R. and Marumo, Y.: Screening of soil evidence by a combination of simple techniques: validity of particle size distribution. Forensic Sci. Int., 122, 155-158 (2001).

6) Pye, K.: Geological and soil evidence, forensic applications. pp. 59-118 Moutain Press, Boca Raton (2004).

7) Thornton, J. I., McLaren, A. D.: Enzymatic characterization of soil evidence. J. Forensic Sci., 20, 674-692 (1975).

8) Horswell, J., Cordiner, S. J., Maas, E. W., Martin, T. M., Sutherland, K. B., Speir, T. W., Nogales, B., and Osborn, A. M.: Forensic comparison of soils by bacterial community DNA profiling. J. Forensic Sci., 47, 350-353 (2002).

9) Heath, L. E., and Saunders, V. A.: Assessing the potential of bacterial DNA profiling for forensic soil comparisons. J. Forensic Sci., 51, 10621068 (2006).

10) Moreno, L. I., Mills, D. K., Entry, J., Sautter, R. T., and Mathee, K.: Microbial metagenome profiling using amplicon length heterogeneitypolymerase chain reaction proves more effective than elemental analysis in discriminating soil specimens. J. Forensic Sci., 51, 1315-1322 (2006).

11) Kuske, C. R., Ticknor, L. O., Miller, M. E., Dunbar, J. M., Davis, J. A., Barns, S. M., and Belnap, J.: Comparison of soil bacterial communities in rhizospheres of three plant species and the interspaces in an arid grassland. Appl. Environ. Microbiol., 68, 1854-1863 (2002).

12) Pesaro, M., Nicollier, G., Zeyer, J., and Widmer, F.: Impact of soil drying-rewetting stress on microbial communities and activities and on degradation of two crop protection products. Appl. Environ. Microbiol., 70, 2577-2587 (2004). 
13) Lueders, T., and Friedrich, M.: Archaeal population dynamics during sequential reduction processes in rice field soil. Appl. Environ. Microbiol., 66, 2732-2742 (2000).

14) Friedrich, M. W., Schmitt-Wagner, D., Lueders, T., and Brune, A.: Axial differences in community structure of Crenarchaeota and Euryarchaeota in the highly compartmentalized gut of the soil-feeding termite Cubitermes orthognathus. Appl. Environ. Microbiol., 67, 4880-4890 (2001).

15) Mahon, B. E., Ponka, A., Hall, W. N., Komatsu, K., Dietrich, S. E., Siitonen, A., Cage, G., Hayes, P. S., Lambert-Fair, M. A., Bean, N. H., Griffin, P. M., and Slutsker, L.: An international outbreak of Salmonella infections caused by alfalfa sprouts grown from contaminated seeds. J. Infect. Dis., 175, 876-882 (1997).

16) Van Der Zwet, W. C., Parlevliet, G. A., Savelkoul, P. H., Stoof, J., Kaiser, A. M., and Van Furth, A. M., Vandenbroucke-Grauls, C. M.: Outbreak of Bacillus cereus infections in a neonatal intensive care unit traced to balloons used in manual ventilation. J. Clin. Microbiol., 38, 4131-4136 (2000).

17) Noller, A. C., McEllistrem, M. C., Pacheco, A. G., Boxrud, D. J., and Harrison, L. H.: Multilocus variable-number tandem repeat analysis distinguishes outbreak and sporadic Escherichia coli O157: H7 isolates. J. Clin. Microbiol., 41, 53895397 (2003).

18）柳原保武, 多村 憲: 微生物学一病原微生物 の基礎一. pp. 122, 南江堂, 東京 (1998).

19) Aguirela, N. H., and Jackson, M. L.: Iron oxide removal from soils and clays. Soil Sci. Soc. Am. Proc., 17, 359-364 (1953).

20) Mehra, O. P., and Jackson, M. L.: Iron oxide removal from soils and clays by a dithionite-citrate system buffered with sodium bicarbonate.
Clays and Clay Minerals, 7, 317-331 (1960).

21）小山正忠, 竹原秀雄: 新版標準土色帖. 日本 色研事業株式会社，東京（1994）。

22) Kuske, C. R., Banton KL, Adorada DL, Stark PC, Hill KK, Jackson PJ. Small-scale DNA sample preparation method for field PCR detection of microbial cells and spores in soil. Appl. Environ. Microbiol., 64, 2463-2472 (1998).

23) Schraft, H., and Griffiths, M. W.: Specific oligonucleotide primers for detection of lecithinase-positive Bacillus spp. by PCR. Appl. Environ. Microbiol., 61, 98-102 (1995).

24) Ohba, M., and Aizawa, K.: Insert toxicity of Bacillus thuringiensis isolated from soils of Japan. J. Invertebr. Pathol., 47, 12-20 (1986).

25) Ohba, M., and Lee, D. H.: Bacillus thuringiensis associated with faeces of the Kerama-jika, Cervus nippon keramae, a wild deer indigenous to the Ryukyus, Japan. J. Basic Microbiol., 43, 158-162 (2003).

26) Andersen, G. L., Simchock, J. M., and Wilson, K. H.: Identification of a region of genetic variability among Bacillus anthracis strains and related species. J. Bacteriol., 178, 377-384 (1996).

27) Valjevac, S., Hilaire, V., Lisanti, O., Ramisse F, Hernandez E, Cavallo JD, et al.: Comparison of minisatellite polymorphisms in the Bacillus cereus complex: a simple assay for large-scale screening and identification of strains most closely related to Bacillus anthracis. Appl. Environ. Microbiol., 71, 6613-6623 (2005).

28) Zahner, V., Cabral, D. A., Regua-Mangia, A. H., Rabinovitch, L., Moreau, G., and McIntosh, D.: Distribution of genes encoding putative virulence factors and fragment length polymorphisms in the vrrA gene among Brazilian isolates of Bacillus cereus and Bacillus thuringiensis. Appl. Environ. Microbiol., 71, 8107-8114 (2005). 